\section{Model 1859 Portuguese army clothes backpack. Historical note, conservation and restoration treatment}

\section{Mochila de roupa do exército português, modelo de 1859. Apontamento histórico e intervenção de conservação e restauro}

\section{ANDRÉ FILIPE DE NUNES FERNANDES \\ 1. Instituto Politécnico de Tomar Quinta do Contador, Estrada da Serra, 2300-313 Tomar, Portugal \\ * andre.fnf@gmail.com}

\begin{abstract}
The model 1859 clothes backpack was used to carry soldier's spare clothing and necessaries. It was strictly made according to a pattern and was constructed in a box shape from leather and canvas, painted black on the exterior. An example of this model, which belongs to the Lisbon Military Museum collection (MML02048), was removed from the storage in 2016 in order to be inventoried. It was subsequently restored within the curricular unit "conservation and restoration project" of the Conservation and Restoration Bachelor so it could be placed on permanent exhibition. This object was likely used in campaign in Mozambique in 1894-95 by the bugler António Moura, taking part on the combat of Marracuene. Areas of deterioration, such as flaking paint and canvas losses, were caused mainly by storage conditions and improper care over the course of more than a century. The treatment was guided towards its ideal state, enhancing mostly historical and aesthetical values which were obtained through investigation. This included restoration of the regulatory polished surface, but maintained the signs of use, such as the mended tears. This paper contributed to the divulgation of detailed information about an unusual type of object within the conservation field and military history.
\end{abstract}

\section{Resumo}

A mochila de roupa modelo de 1859 era utilizada para transportar a roupa de reserva dos soldados e o pequeno equipamento. Era feita de acordo com um padrão, construída em forma de caixa a partir de cabedal e lona, pintada de preto no exterior. Um exemplar deste modelo, pertencente à coleção do Museu Militar de Lisboa (MMLO2048), foi retirado da reserva em 2016 para ser inventariado. Foi subsequentemente restaurado no contexto da unidade curricular "projeto em conservação e restauro" da Licenciatura de Conservação e Restauro, de forma a ser colocado em exposição permanente. Este objeto foi provavelmente utilizado em campanha em Moçambique em 1894-95 pelo corneteiro António Moura, tendo participado no combate de Marracuene. Áreas de deterioração, tais como destacamentos e lacunas na lona, foram causadas sobretudo devido a condições de acondicionamento incorretas ao longo de mais de um século. $O$ tratamento procurou ir ao estado ideal da mochila, realçando principalmente valores históricos e estéticos, que foram obtidos através de investigação. Isto incluiu o restauro da superfície polida regulamentar, mas manteve os sinais de uso, tais como os rasgões remendados. Este artigo contribuiu para a divulgação de informação detalhada sobre um tipo de objeto pouco comum dentro da área de conservação, e história militar.

\section{KEYWORDS}

Canvas

Leather

Individual equipment

Marracuene

Military

Heritage

\section{PALAVRAS-CHAVE}

Lona

Cabedal

Equipamento individual

Marracuene

Militar

Património 


\section{Introduction}

In the late 19th century/early 2oth century a backpack and the remaining equipment set (comprising of a mess kit, canteen, haversack, ammunition pouches, frog, leather belt and several leather straps), 6 other identical equipment sets, 36 rifles, 6 bugles and 2 drums were incorporated in the Lisbon Military Museum (LMM) collection and exhibited in the Dona Maria Pia room.

These objects were used in 1895 in Africa, and some were present in the conflicts of Marracuene and Coolella, and in the actions of Manjacase and Chaimite [1]. In May 2016, during an internship at the LMM a group of several of these objects were removed from the collection storage in order to be inventoried. The previous museum catalogues and photos had scarce to no information; these objects were not yet recorded on the modern inventory system database.

One of these objects was a backpack (current inventory MLLO2048) which had a metal mess kit strapped to its front (Figure 1), with a handwritten card stored inside. The museum was interested in placing this backpack on permanent exhibition due to its unique contents, but it presented conservation issues. As such, it underwent treatment as part of the Conservation and Restoration Bachelor of the Polytechnic Institute of Tomar, in order to be exhibited.

This project presents a unique contribution to the heritage conservation literature, as well as, to Portuguese military history literature, since there are no publications about this model. Individual equipment, or accoutrements pertain everything a soldier uses/wears other than its uniform and weapons. In Portugal these are undervalued when compared with weaponry and uniforms; therefore, this project provided detailed information about a particular Portuguese 19th century accoutrement.

\section{Historical note}

\section{Model development, production and use context}

The model 1859 backpack was used for more than 40 years by the Portuguese Army. Initially it was designed to serve infantry troops, but later ended up serving artillery and engineering troops as well.

It was gradually replaced by the model 1894 backpack, although an article written in 1908 states that model 1859 backpacks were still used within the 27 th infantry regiment, even though these had "dirty canvas, mended several times, nearly rotten, in which clothes could not be placed inside, without the risk of bursting" [2, p. 40].

It is similar to British models such as the "Trotter" or "box" type. This resemblance might be explained in part due to the relation with Great Britain during the Peninsular War, by which time it started providing backpacks to the Portuguese Army [3]. Between 1849 and 1856 several experiments to upgrade the infantry and light infantry equipment took place; these experiments were reported in the Revista Militar [4-8]. Overall the experiments resulted in the production and testing of several different models of backpacks and straps, outcoming in the adoption of one model of backpack, in 1856, whose design was attributed to Captain Cunha Salgado [8]. In the following years there is no more information pertaining to backpacks, and all that is known is the model year of the 1859 backpack.

The LMM backpack was identified as being the model 1859 clothes backpack by consulting period literature [9-10] and by comparing it with its pattern. Patterns were introduced in the Fábrica d'Armas (F.A.), in Santa Clara, Lisbon, by the Baron of Monte Pedral, José Baptista da Silva Lopes, in the first half of the 19th century, with the intent to provide "perfection and uniformity" in the production of the

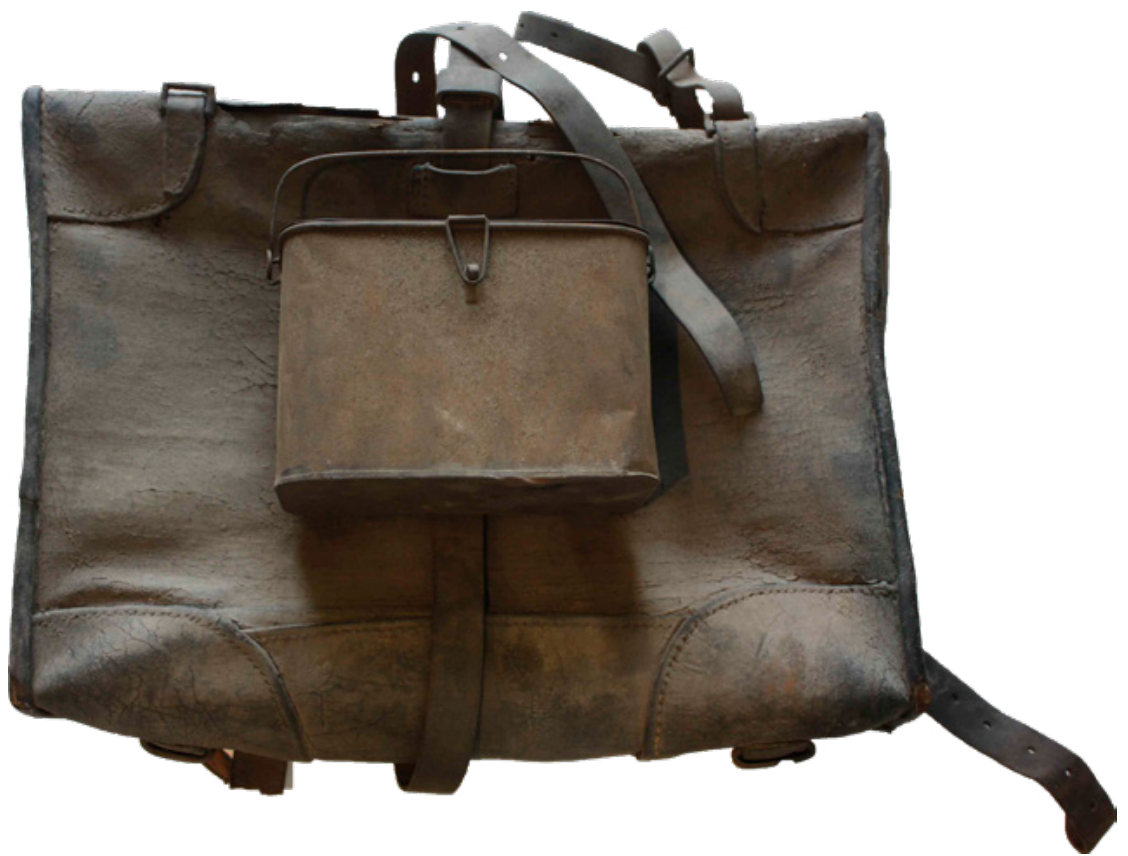

Figure 1. Lisbon Military Museum model 1859 backpack (MMLO2048) and mess kit after being removed from the museum storage. Photograph taken on the 31 st of May 2016. 


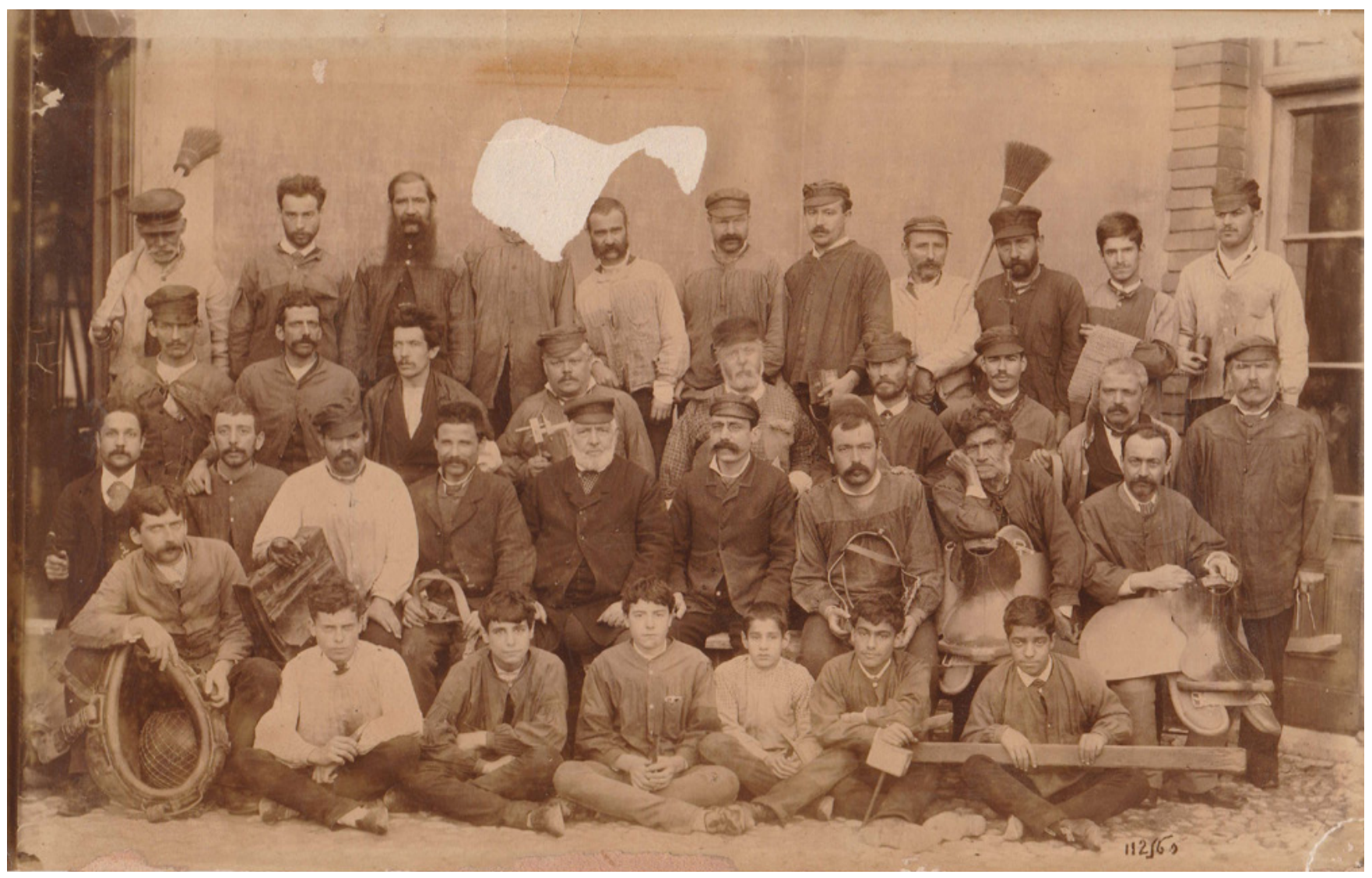

Figure 2. Group photo from the late 19th century depicting a group of craftsmen and apprentices at the Fábrica d'Armas, in Lisbon. The man on the third column from the left and second row from the bottom is holding a model 1859 backpack. From the Núcleo Museológico das Oficinas Gerais de Fardamento e Equipamento collection. Unknown author.

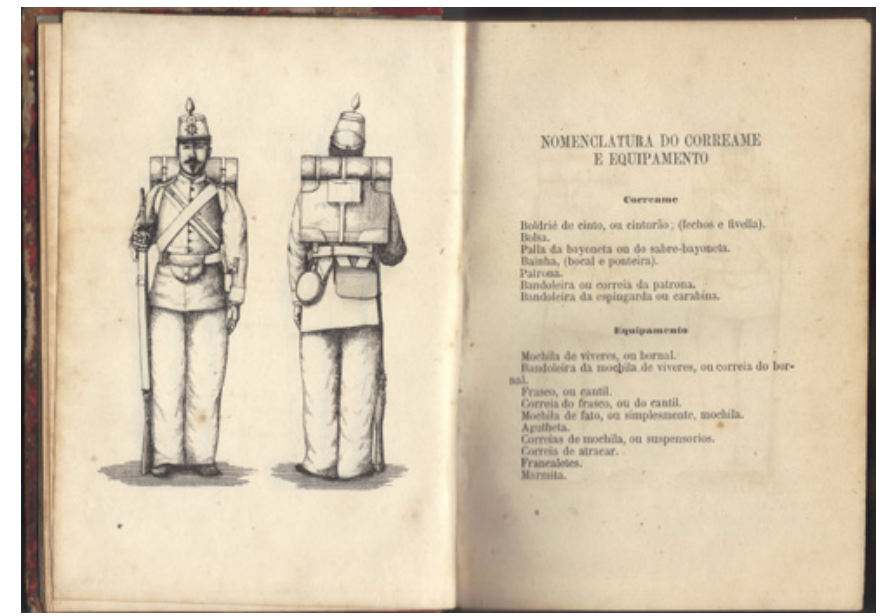

Figure 3. Print from the page 11 and 12 from the 1879 book "Ordenança sobre os exercicios e evoluções dos corpos de infantaria. Livro I" depicting an infantry soldier seen from the front and back carrying a model 1859 backpack. From the authors collection.

respective model [11]. Generally, this model was produced at the F.A. as well (Figure 2), and it was common for models to be stamped with the factory initials and manufacture date (i.e. F.A. 1879). Manufacturing stamps could not be found on this backpack, and, at the moment, there is no certainty about where it was produced.

As with most military backpacks of the time, the model 1859 backpack was designed to carry spare clothing and necessaries, the overcoat and the mess kit [10, 12-14] (Figure 3). According to period literature it was packed in a regulation manner, with a specific number of articles, arranged in a pre-determined way: boots, jackets, shirts, cap, trousers, long johns and necessaries $[10,13]$. The remaining equipment was ordered by the mess kit, haversack, canteen, two ammo pouches and the belt with the frog. Some variations were common according to the year and branch, such as the use of white buff leather straps within line infantry [15] and artillery, as opposed to the black vegetable tanned leather straps used by light infantry.

\section{Association with António Moura}

During the process of documentation, a handwritten card was found inside the model 1859 mess kit which states:

Regiment No. 2 of light infantry (missing).

Distributed to the bugler António (missing)

14/2025 of the 3rd company of the 2nd battalion (missing)

Dispatched in Anguane from the 9th to the 22nd of

January 1895. In Marracuene from the

28th of January to the 7 th of February

1895

António Moura was born on the 1st of November 1869 in 


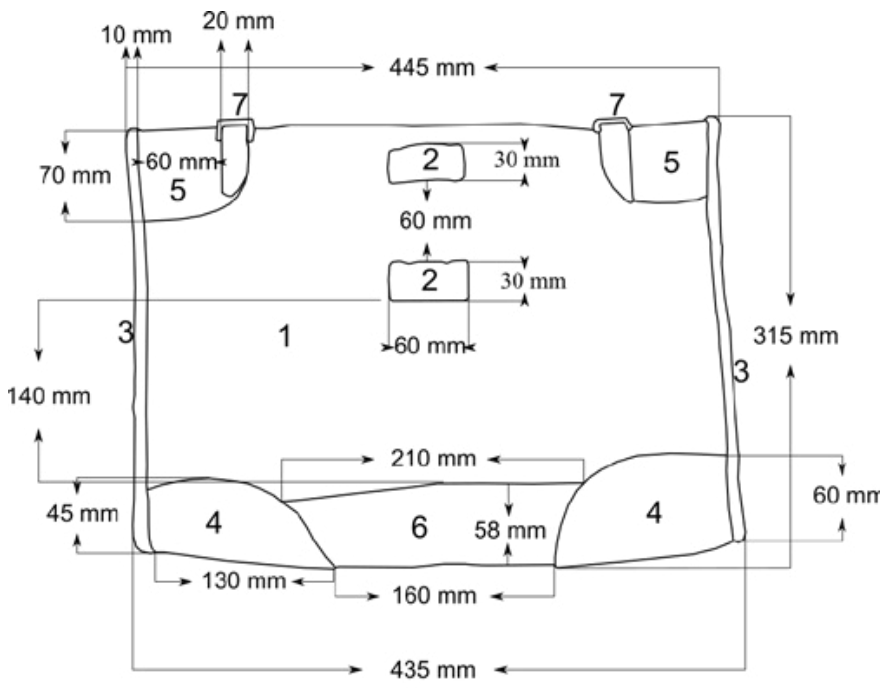

$a$

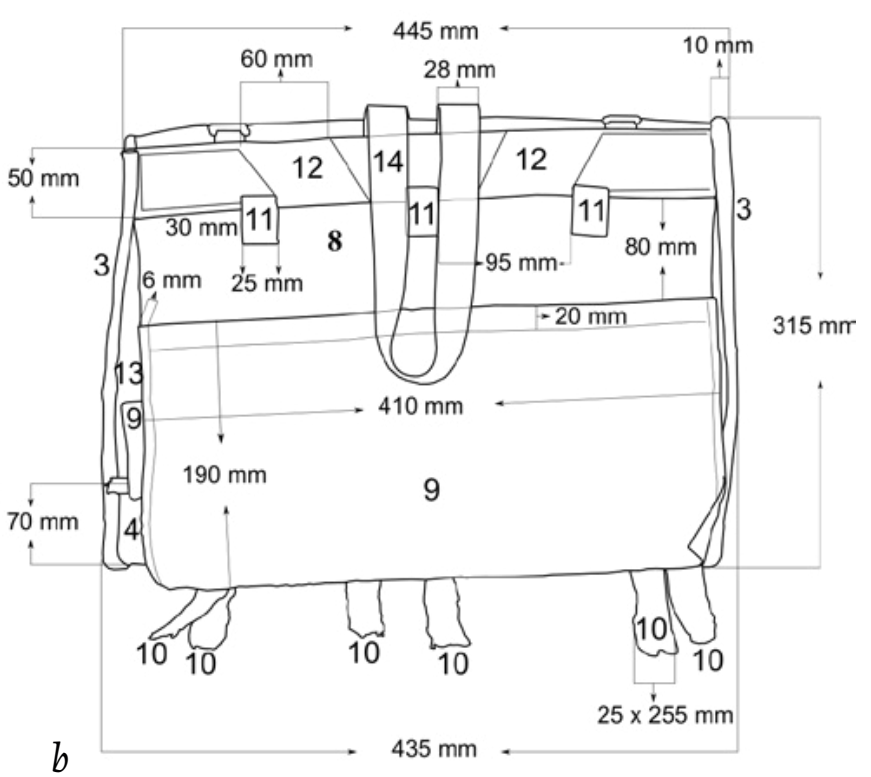

Figure 4. Backpack graphic outline of the front (a) and back (b) with its dimensions and numbered components. 1-front lining; 2 - front loops; 3 - side hems; 4- bottom corner reinforcements; 5- upper corner reinforcements; 6- bottom reinforcement; 7- upper loops; 8- back lining; 9- flaps; 10- tapes; 11- pin loops; 12- shoulder straps loops; 13- back reinforcement; 14- hanging loop.

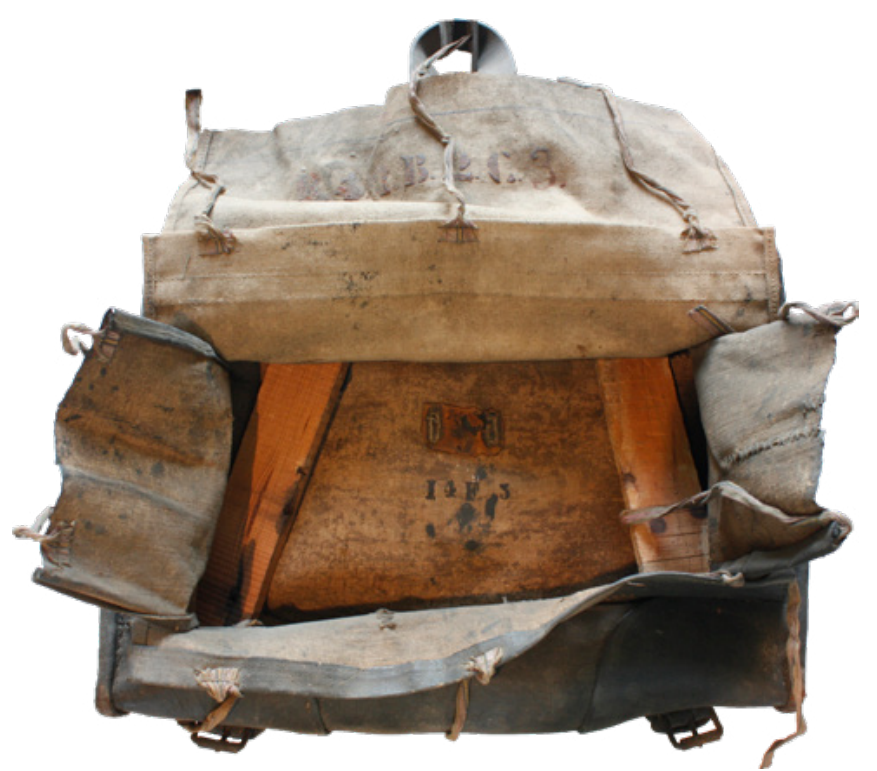

Figure 5. Backpack seen from the back with all the 4 flaps open, giving access to the interior compartment. Notice two wooden boards on the interior, and a mended tear on the center of the right flap. Photograph taken on the 31st of May 2016.

the locality of São Miguel da Acha, council of Idanha-a-Nova, district of Castelo Branco [16].

On the 13th of April 1892, at the age of 22, Moura joined the 3rd company, 1st battalion, 2nd regiment of the Queen's light infantry, as private No. 52, with the registration No. 1908 [17]. On the 5th of December he was transferred to the 1st company as private No. 14, first as an apprentice bugler, graduating to bugler on the 4th of April 1893, where he was then transferred to the 3rd company of the 2 nd battalion, again as Private No. 14 [18].
Meanwhile, in August that year, in Lourenço Marques, modern Maputo, there was a revolt by locals of the lands of Magaia, Zixaxa and Moamba, against Portuguese rule. This was triggered by the increase in the tax of huts, resulting in several attempts to seize the city [19].

As a response to this revolt, on the 15th October 1894, Moura's battalion marched from Valle Pereiro to the Navy Arsenal, boarding the steamboat Cazengo for a journey through the Cabo da Boa Esperança which lasted 27 days, with destination to Lourenço Marques [19].

The first contact with local warriors was in Anguané on the 5th of December 1894 [20], however, the most decisive moment occurred on the 2nd of February 1895, at around 4 a.m. in Marracuene. There, a battle took place between Portuguese troops and 2,500 local warriors [20-21]. This battle was later known as Combate de Marracuene in Portugal, or Gwaza Muthini in Mozambique, and nowadays it is still celebrated in Mozambique.

\section{Description of the model 1859 backpack}

The LMM backpack has a rectangular shape and measures $445 \mathrm{~mm}$ in width, $315 \mathrm{~mm}$ in height and $145 \mathrm{~mm}$ deep (Figure 4). It is black throughout the exterior. Access to the single interior compartment is made from the reverse, which is closed with two layers of flaps and 10 tapes (Figure 5). All four corners and the bottom are reinforced with panels, it has two strap loops on the front and four on the top, and the shoulder straps are removable with the use of a pin, which locks them in place near the top (Figure 6). It has an internal 
volume of approximately 20 liters, and with its shoulder straps and metal pin it has a mass of $1.97 \mathrm{~kg}$.

It is constructed from a total of 9 different materials within 4 material groups (textiles, leather and related materials, metals and surface coatings).

Within the textiles, canvas is used for the main material of the backpack; it is made from a tight basketweave in which groups of 2 warp threads interlace with one weft thread, giving the canvas a density of $22 / 11 \mathrm{~cm}^{2}$ warp/weft threads, with a $\mathrm{Z}$ twist. Its fibers as well as the fibers of the stitching were analyzed longitudinally, and they are from flax or hemp (this can only be confirmed with a cross section analysis). The tapes that close the flaps, each measuring 25 $\times 255 \mathrm{~mm}$, are made from cotton; these are made in taffeta weave, with a total of 47 warp threads dyed in 6 different colors: the 3 outermost threads are beige, followed by 4 green threads, 4 magenta threads, 8 threads in a blend of white and purple, 3 blue threads, and at the center 3 yellow threads, following the same pattern in the inverse order (blue, purple/white, magenta, green, beige). On the interior there is a lining behind the reverse, parallel to the innermost flaps, which resembles wool felt.

Within the leather and related materials group, vegetable tanned leather is used on the sides and hems, upper corner reinforcements, loops on the back, hanger loop, shoulder straps and on all the interior reinforcements. The bottom reinforcements and the strap loops on the front are made from alum tawed leather.

Within the metals, the loops on the top, the buckles on the bottom and the shoulder straps pin are made from an iron alloy.

There are also 3 different types of surface coatings of unknown composition. One covers the entire exterior surface of the backpack, canvas and leather parts alike, as well as the metal buckles and loops; it is a black coating. According to period instructions the canvas parts were waxed "the same way as footwear", but the leather parts "after being painted" were waxed "according to the 1856 instructions" [15, p. 113114]. The recipe for the latter treatment is provided in the instructions [14], but there is no mention of a recipe for waxing footwear. Further investigation on the manufacture of this type of objects allowed the discovery of yet another recipe, for a black paint to be used on "vegetable tanned leather, sole leather, etc" [22, p. 101]. This paint was made with sumac leaves, iron sulfate, lamp black, tallow and gum.

The other two coatings are part of regimental markings and are located in the interior of the backpack (Figure 5). One is located on the reverse of the outermost flap; it resembles a red paint or paste and has the following letters/numbers:

$$
\text { R.4:2.B.2.C.3 }
$$

The other marking is located on the underside of the front, below the leather reinforcement of the bottom strap loop. It is black and very thin, resembling an ink, and has the following letters/numbers:

$$
\text { I4F3 }
$$

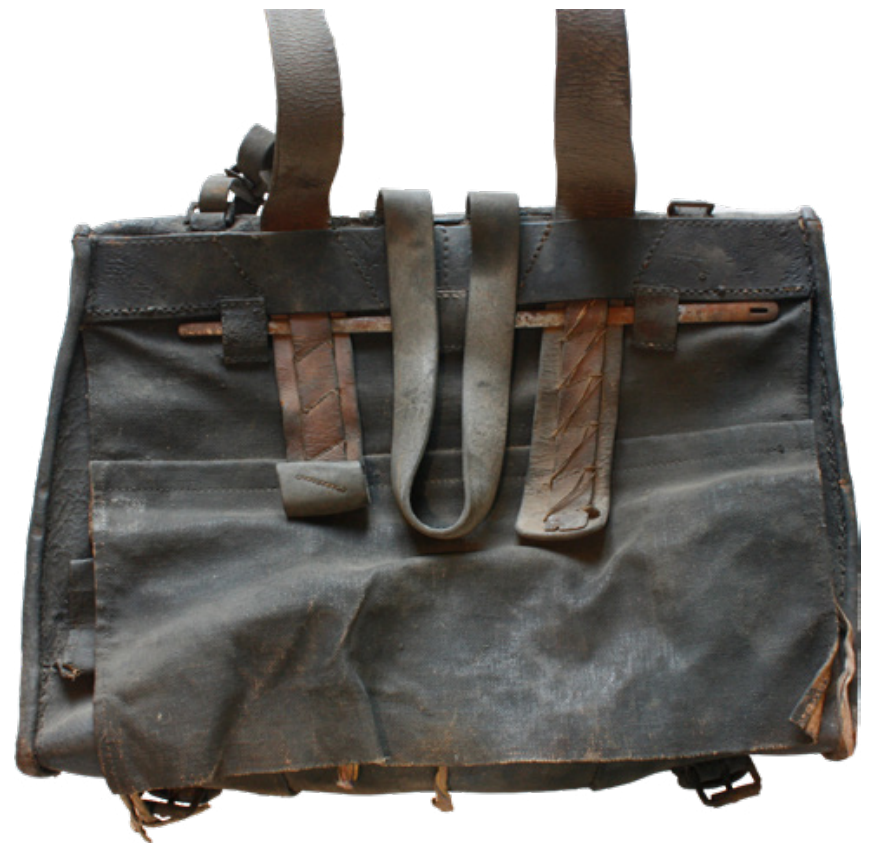

Figure 6. Backpack seen from the back, showing the metal pin connecting the top of the shoulder straps to the body. Comparing the stitches on this example with other m/1859 backpacks, it appears that it has 2 left shoulder straps, instead of a left and right shoulder strap. Photograph taken on the 31st of May 2016.

\section{Condition of the backpack}

The LMM backpack appears to have been stored in the same place for a long time, front side up, without any covering. The mess kit was strapped to the front, and four wooden boards were on the interior the backpack facing the sides, top and bottom walls. There was no interior padding.

Its front, bottom, top and sides were full of dust. The interior also had dust, as well as particulate matter, and traces of plant matter (the same type of plant matter was also found inside the mess kit). The shoulder straps were dusty and had some type of grease. The overall shape was deformed due to the use of the wooden boards.

\section{Textiles}

Overall, the canvas had numerous distortions due to the weight of the mess kit, as well as 11 tears and 6 losses.

It had 2 untreated tears in the front, one of them where the rear bottom left corner of the mess kit was touching the canvas, and the other where the canvas meets the bottom leather reinforcement. The left, right and bottom flaps had 2 untreated tears each.

The bottom and right flaps each have 2 other tears, which were mended; as does the front of the canvas, where it meets the leather reinforcement in the top right corner (Figure 7). These are repaired with a type of thread similar to that used in the necessaries and appear to have been made during the time this backpack was used.

It also had 5 losses in the top portion of the front; 1 in the right side, longer than $120 \mathrm{~mm}$, and the remaining towards 


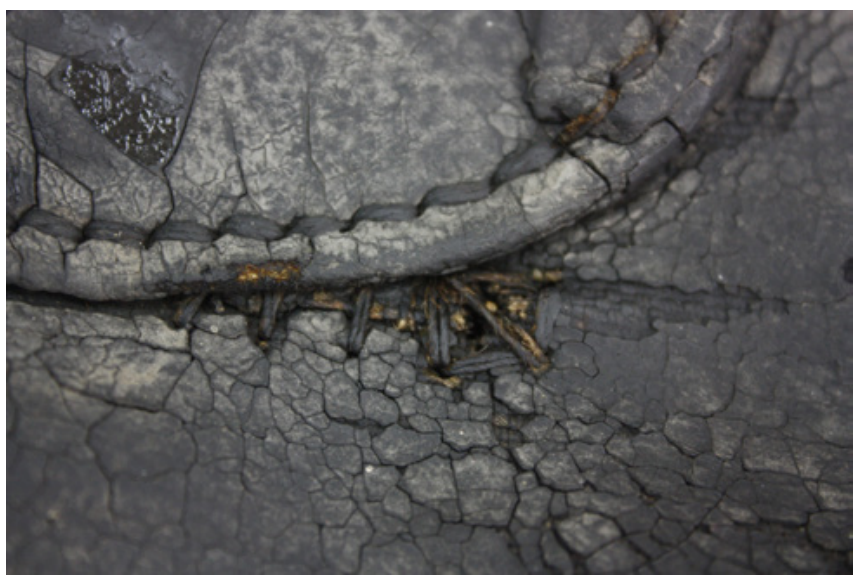

Figure 7. Mended tear on the top right corner of the front. Photograph taken on the 14th of November 2016.

the left side, with the biggest one around $20 \mathrm{~mm}$ long. The bottom flap had a small loss. The top wooden board was beneath the losses on the top portion, and most of that area had been painted black, including the board (Figure 8).

The tapes were soiled and coiled in a clockwise manner. The coiling of the tapes seems to be a result of usage.

\section{Surface coatings}

The black surface coating had lost most of its adhesion to the canvas, and overall presented a network of aged cracks, flaking, lifting and losses (Figure 8).

The network of cracks is present on the entire coating, except for the metal parts. The cracks have a specific pattern according to the underlying material, whether it is leather or canvas, with the latter being grouped closer.

Flaking, lifting and losses were mainly on the coating over the front canvas and inner flaps.

The red marking located on the underside of the outermost flap had lost most of its cohesion, and all the letters had flaking and losses.

\section{Leathers}

The inner part of the side leather panels, as well as the bottom corners of the hems, are abraded. All the interior leather reinforcements have some abrasion and loss of cohesion. Overall the shoulder straps are abraded and have several cracks along their entire length; one of these straps is missing the last $255 \mathrm{~mm}$ of its lower end.

\section{Metals}

Overall the metal buckles, loops and pin had corrosion products.

\section{Goal of treatment}

According to Appelbaum the ideal state is "the state that best embodies the object's values" [23] and "is one of its past

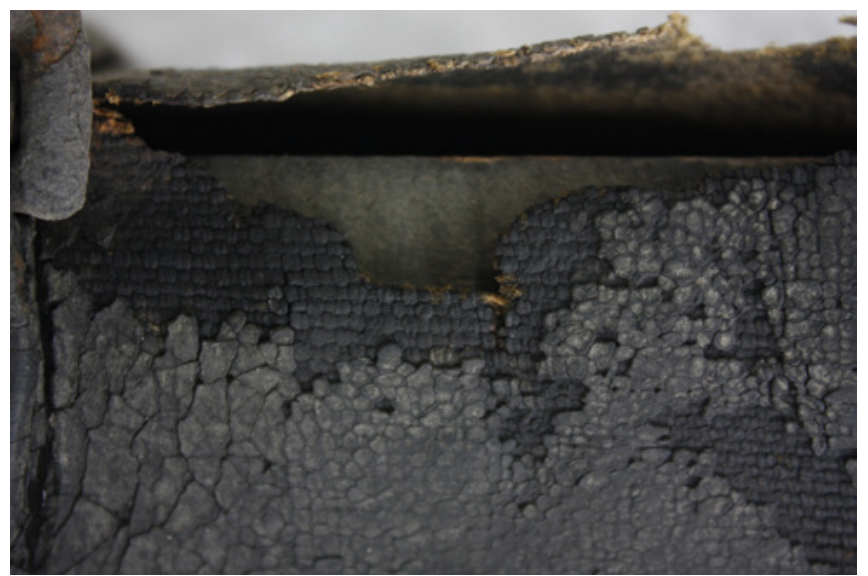

Figure 8. Loss of canvas and surface coating, as well as cracking, on the right top of the front. Notice the wooden board painted black beneath the canvas. Photograph taken on the 14th of November 2016.

states" [24]. This backpack had several past states, each with its own values. It was made most likely in the 1880s, probably used in campaign in 1894-95, in the 1900 s exhibited in the museum, and sometime in the zoth century stored, until its recent discovery. Nowadays it has lost all of its functional value, but other values have increased. This cultural object is a witness of past events, and studying it allows us to learn more about the past. Therefore, it must be preserved in order to maintain certain aspects that are true to its time and enhance its values.

Considering the high historical value converging mostly in the period when the object was last used for its purpose, it was decided that the ideal state should correspond with that period, or at least within the time it entered the museum collection. For this goal to be realistically achieved, not only was a conservation treatment required, but also a restoration treatment.

The general treatment methodology was planned in the following manner:

- Mechanical cleaning of the surface and interior of the backpack to facilitate further treatments and remove material which can, over time, cause further damage;

- Removal of iron corrosion products to stabilize the deterioration of the metal components;

- Consolidation of the surface coatings since it was to be placed on permanent exhibition, and would most likely be loaned for temporary exhibitions;

- Removal of distortions of the canvas for aesthetics and to relax tensions on the fibers, but most of all to treat the canvas losses and tears;

- Treatment of tears and losses on the canvas. Not only is this a restoration treatment since it has an important aesthetical function by replacing lost material, but it is also a conservation treatment, as it provides structural support on fragile areas;

- Inpainting of losses and application of a surface finish. A purely restoration treatment, it is one of the most important steps in achieving the ideal state, since it 
enhances certain aesthetic values that were attributed to this object at the time it was used. An article written in 1855 dedicated to the introduction of a new recipe of black wax [25] (the same mentioned in the instructions [15]) reflects the importance attributed to the appearance of the equipment, and a polished shiny surface was mandatory.

The mess kit that was found strapped to the backpack was also treated within the curricular unit, however, the focus of this paper is on the conservation of the backpack itself. The wooden boards, the traces of plant matter and the card were stored separately for future study.

\section{Conservation treatment}

\section{Textiles}

The interior of the backpack was mechanically cleaned with an Akapad (a.k.a. Wishab) soft sponge, soft bristle brush and a vacuum cleaner.

To remove the distortions of the canvas the fibers were relaxed with an ultrasonic humidifier with distilled water and then weighs were placed on the interior to maintain the correct shape while drying. The water vapors were applied at room temperature to protect the leather components, which are sensitive to heat in the presence of water and can shrink irretrievably [26].

In repairing the tears these were temporarily aligned and secured with Filmoplast P 90 tape, and then welded with Lascaux polyamide textile adhesive 5060 (Figure 9a). Afterwards BEVA 371 film was applied on top of the tear and set in place with a tacking iron at $65^{\circ} \mathrm{C}$ (Figure 9b). BEVA 371 is considered a reasonably stable adhesive on canvas substrates [27]. Finally, a Reemay reinforcement was set on top of the film adhesive (Figure $9 c$ ).

For filling the losses, the treatment was similar to that used above for mending the tears. Linen fabric similar in weave to the original canvas was cut to the size and shape of the losses. These pieces were then temporarily secured in place with the tape, and welded to the canvas with textile polyamide, and a Reemay reinforcement was secured with the film.

The tapes were treated mainly for aesthetical reasons. They have a pleasing appearance, in 6 different colors, which contrast with the plain black color of the backpack. Since they were coiled, they could not be fully appreciated, hence it was decided to flatten just the outer tapes and leave the inner ones untouched, since the coiling was most likely a result of period use and has historical value. They were moistened using a sponge with lukewarm deionized water, placing absorbent paper beneath, and then flattening the tapes with a tacking iron set to $60^{\circ} \mathrm{C}$ and Melinex film in between.

\section{Surface coatings}

The treatment on the black coating began with mechanical
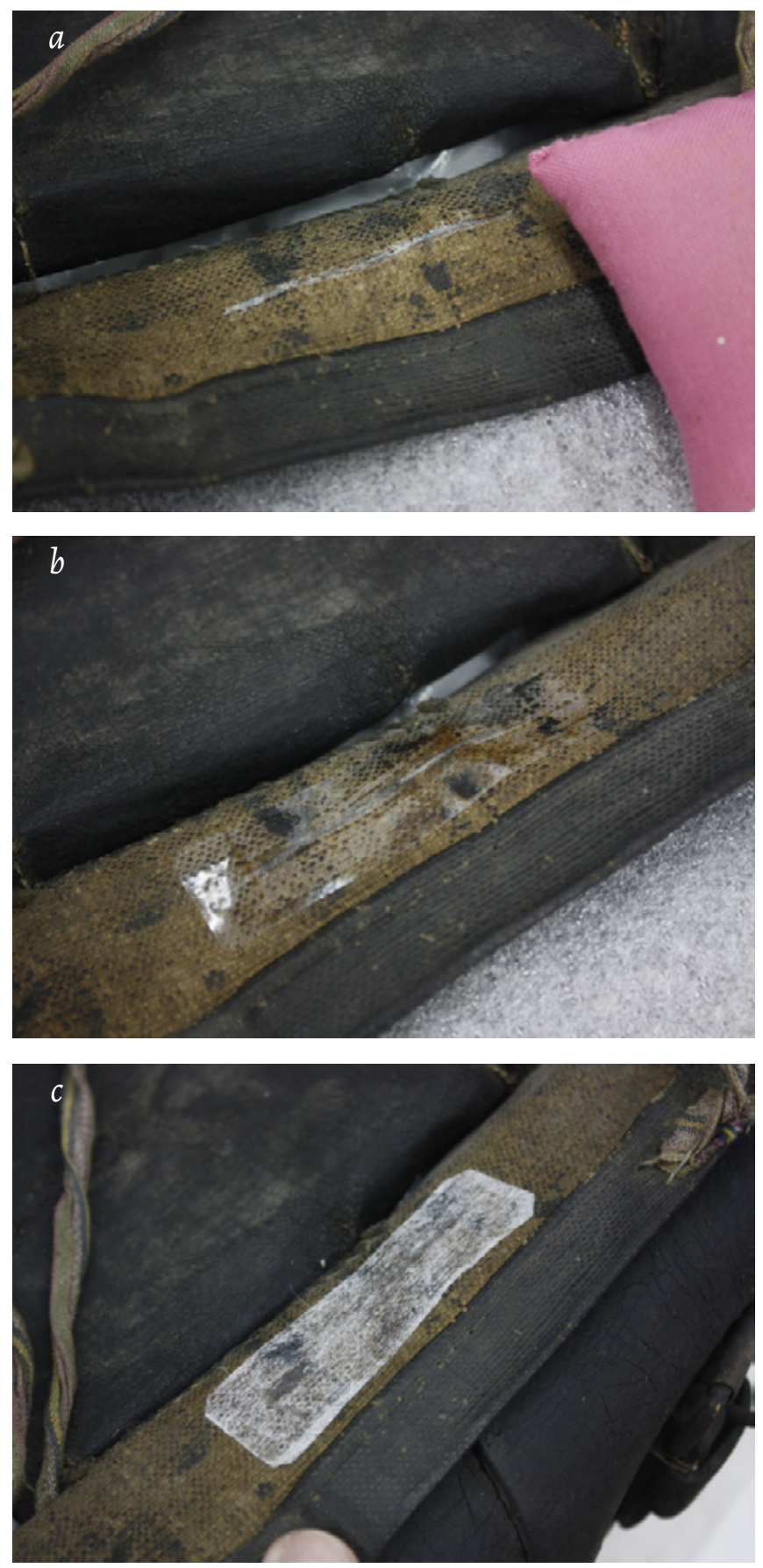

Figure 9. Tear mending, during welding (a), application of BEVA 371 film (b) and application of a Reemay reinforcement (c). Photographs taken on the 29 th of May 2017.

cleaning using a soft bristle brush, however, this coating was too fragile, and some detachments were noticed. This treatment was ceased, and a consolidation treatment took place, on this coating and on the red marking.

The choice of treatment material began with assessing the solubility of the coatings. Two solvents were initially tested, a polar and a non-polar solvent, i.e. deionized water and white spirit. A mixture of deionized water with ethanol (1:1 v/v) was also tested. Cotton swabs were used. Both the black and the red coating were slightly dissolved with water, leaving residues on the cotton; with the water-ethanol 
mixture these layers were even more affected. The white spirit had no dissolution of the black or red layer.

Three adhesives were tested before consolidation: BEVA 371 in white spirit at $15 \%$, Klucel G in water-ethanol mixture $(1: 1 \mathrm{v} / \mathrm{v})$ at $3 \%$ and methyl cellulose in water at $0.5 \%$. All three adhesives were successful in adhering the coatings to the canvas, however, since both the Klucel and methyl cellulose are used with polar solvents there was a considerable risk of dissolving the coatings. For that reason, BEVA 371 dissolved in non-polar solvents, was chosen for consolidation.

This adhesive has become a standard for conservators around the world [28]. Although it was originally developed for the lining of paintings [29], Berger has showed that it can be used for consolidation treatments from the front of paintings [28-29]. However, its use has raised some concerns regarding removability and optical properties [28]; photodegradation of this adhesive can have consequences on its solubility, and oxidation can cause yellowing both in dark and light conditions [29]. In summary, its use on this backpack could mean that, given enough time, the adhesive will be less soluble and in theory, it could change the color of the surface. However, regardless of the material used, when a consolidation material is introduced, generally it is hard if not impossible to be completely removed, and in this particular case the consolidation of the black coating was an important and necessary step for conservation of the backpack. Also, given that the coating is black, and a finish was to be applied, the yellowing of the adhesive was not a major aesthetical concern.

For the consolidation itself, the adhesive solution was warmed to its activation temperature of $65^{\circ} \mathrm{C}$ [28] on a hot plate prior to application by brushing. This method was preferred over the use of a heated spatula because the coating was somewhat thick $(\approx 130 \mu \mathrm{m})$ and using a spatula could result in insufficient heat transfer.

The consolidation on the black coating was achieved with 3 different concentrations of BEVA adhesive. A solution at $15 \%(\mathrm{v} / \mathrm{v})$ was applied twice on the front (Figure 10), and on the interior flaps. At a $25 \%$ concentration the adhesive was applied on the front, in areas where the coating was still detaching from the canvas, i.e. on the lower corners which had creases, and where the mess kit corners previously touched this coating. And lastly, the application of adhesive at a $65 \%$ over the metal buckles and loops after the corrosion treatment. Since this coating was also applied on these parts, and due to the corrosion, there were some detached flakes. With this concentration there were also some minor applications of adhesive on the lowest part of the front, where the canvas meets the leather reinforcements, which were still showing some detachments on the creases. The high concentration of adhesive left residues on the surface; these were cleaned with cotton swabs embedded in ligroin. Being more volatile than white spirit, ligroin allowed the removal of the residues on the surface without reactivating the adhesive.

The remaining treatments on the black coating were done mainly for aesthetical reasons, and consisted of inpainting the newly inserted linen fabric and applying a finish.

For the inpainting, the recipe on the instructions [15] was reproduced and used as both a filler and inpainting material for the losses, since it provided the ideal consistency, texture and color. It was made with beeswax, bone black pigment, colophony and turpentine, and was applied only on the new fabric, with a spatula (Figure 11).

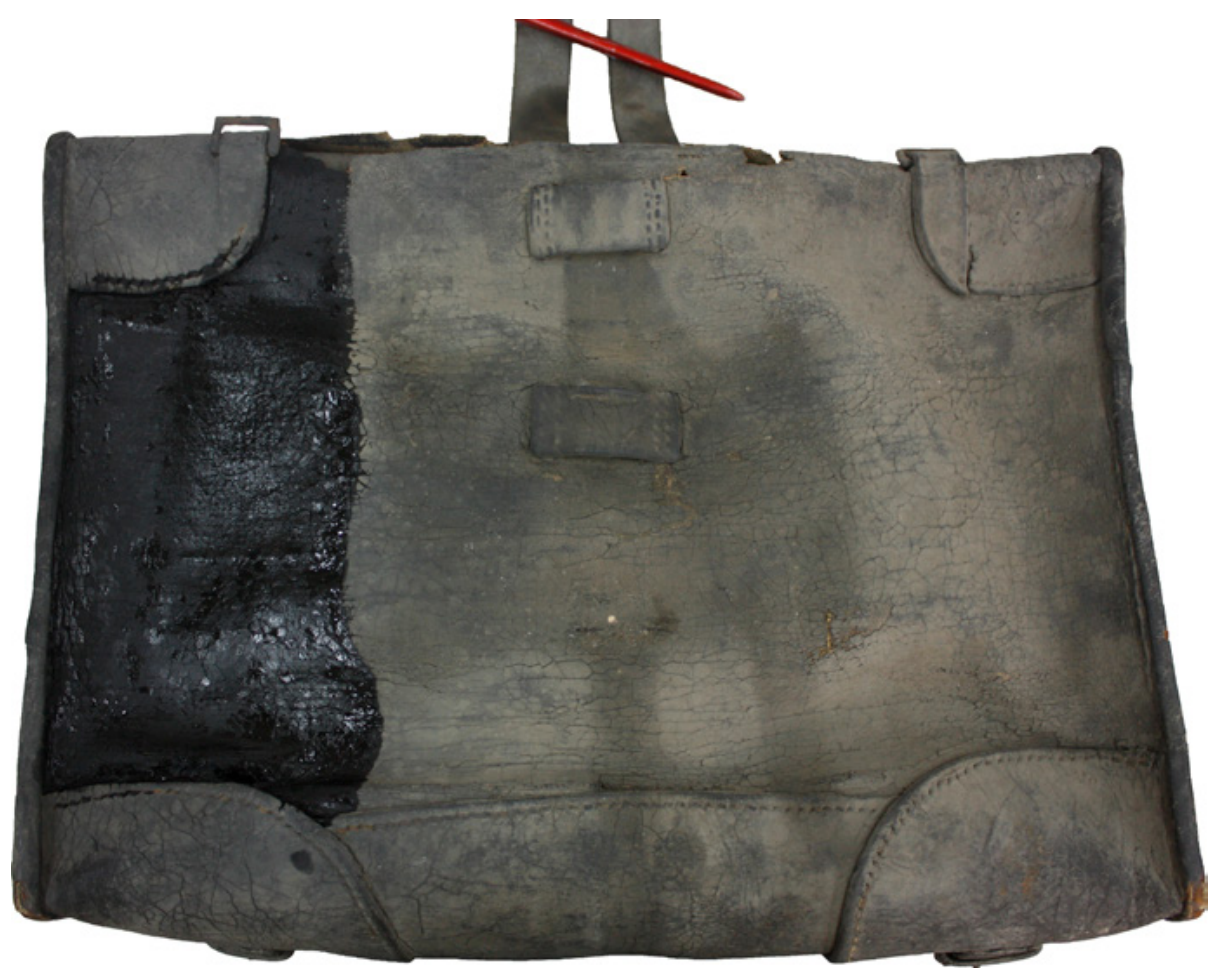

Figure 10. Consolidation treatment on the front. Photograph taken on the 14th of November 2016. 

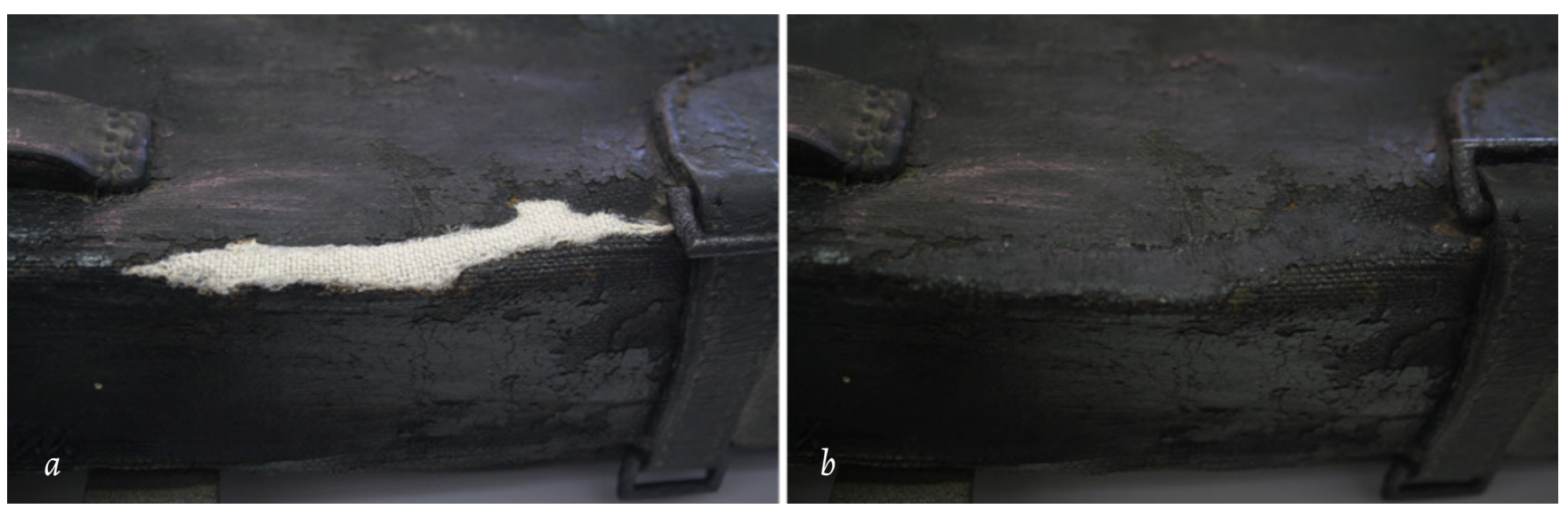

Figure 11. Canvas insert before inpainting (a) and after inpainting (b). Photograph taken on the 17th of July 2017.

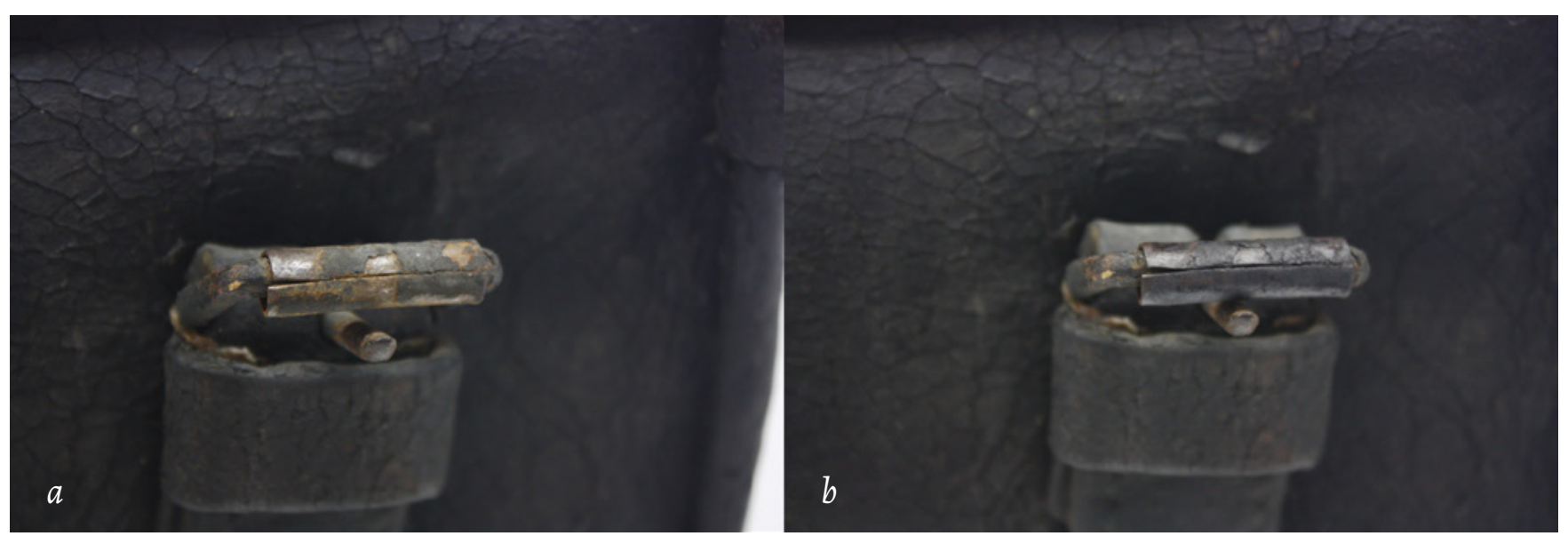

Figure 12. Buckles before (a) and after (b) treatment with tannic acid solution. Photographs taken on the 26th of June 2017.

For a final finish, which both protects the surface and makes it shine in a similar way to the time this backpack was used, microcrystalline wax dissolved in white spirit was used, applied with a clean rag over the front, top, bottom and sides. After the evaporation of the solvent the surface was first checked to see if the consolidation treatment had been affected by this treatment, and afterwards it was buffed with a brush, which provided a shiny appearance.

\section{Leathers}

The shoulder straps were first cleaned with soft brushes and a vacuum cleaner, which removed most of the loose dust particles. Afterwards an Akapad soft sponge was tested, but it had little effect, since at some point these straps were conditioned with a waxy material. This material was removed with solvents; initially with cotton swabs embedded in white spirit, and later finished with toluene.

\section{Metals}

The presence of the black coating on the buckles and loops, and the fact that these are permanently attached to the body of the backpack, meant that the removal of all corrosion products could not be fully achieved. The loosest corrosion was first removed with a scalpel blade No. 15. Then a solution of tannic acid in distilled water in a concentration of $3 \%(w / v)$ with a few drops of isopropyl alcohol to reduce the surface tension was used. Tannins in acidic solution act as corrosion inhibitors by forming ferric-tannates multilayer on the surface of the metal and by creating a blocking effect by the chemisorbed tannin molecules [30]. This treatment has the advantage, in this case, to produce a black color (Figure 12), since the buckles were originally black. The solution was applied with a small brush prior to the consolidation of the coating.

The treatment on the metal pin was different from the treatment on the buckles and loops because a black color was not desired nor originally existed, and a more efficient approach was possible to execute. The pin was initially cleaned with an Akapad hard sponge, and the loosest corrosion products were removed with a brass bristle brush. Afterwards a solution of ethylenediaminetetraacetic acid (EDTA) in distilled water was applied $(10 \% \mathrm{w} / \mathrm{v})$. The pin was wrapped in hydrophilic cotton impregnated with this solution and left to act covered with Mylar for two days. It was then cleaned with distilled water and a 1200 grit wet sandpaper and dried with absorbent paper and isopropyl alcohol. To protect it from oxidation a protective layer of Paraloid B72 was utilized, since this resin forms an effective coating against pollutants and water permeability [31]. It was applied dissolved in xylene $(10 \% \mathrm{w} / \mathrm{v})$ with a brush; the pin being hung up to let the solvent evaporate. 

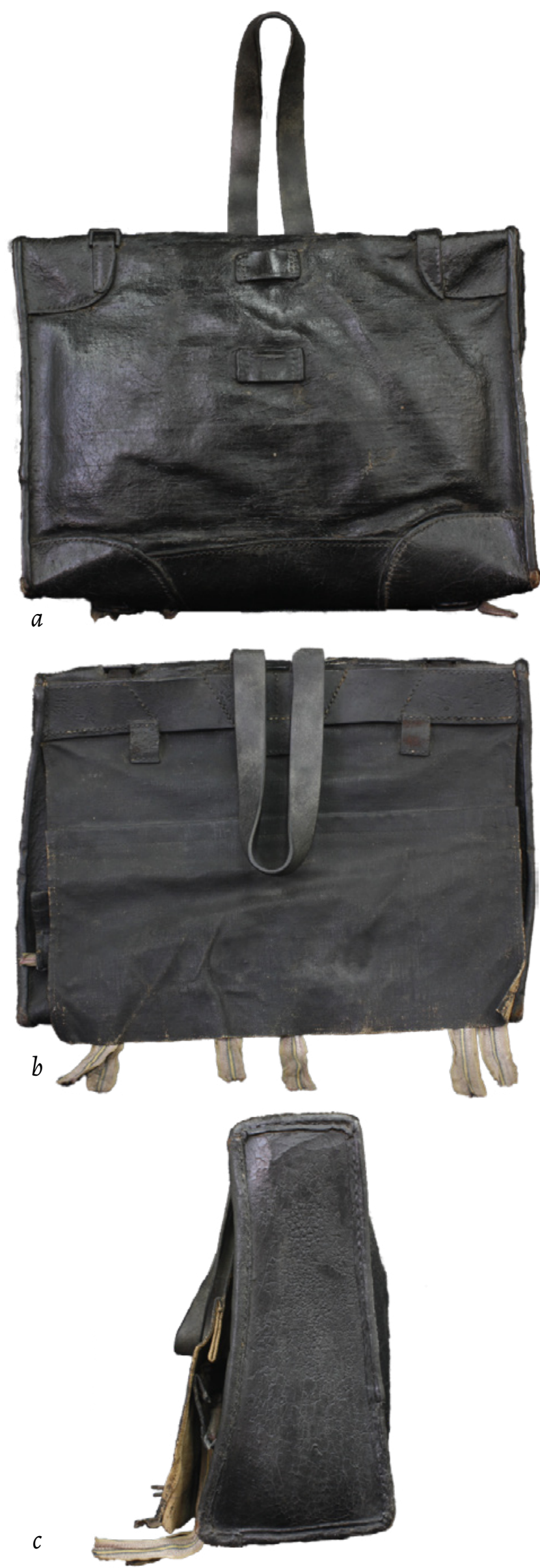

Figure 13. Backpack seen from the front (a), back (b) and right side (c), after conservation and restoration treatment. Photographs taken on the 26 th of July 2017.

\section{Conclusion}

The initial objective that led to the removal of this backpack from the museum storage was mainly to have it registered in the inventory database. At the time, a full conservation and restoration treatment was never intended; however, the unique history of this backpack meant that long-term display/permanent exhibition was desired and stabilization and aesthetic restoration was necessary. As a result, it was possible to study an otherwise unknown object, and enhance its major values and cultural significance.

The conservation and restoration treatment made it possible to exhibit this object once more. The choices for a realistic goal of treatment were guided towards the ideal state, providing a close visual reference to what it is assumed to be the look of this backpack by the time it was being used for its intended purpose (noting that a full reversal of its previous state is not possible) (Figure 13).

Among the objects found in 2016, there were two other backpacks of this same model. At the moment these are being studied within the master's degree, and it is intended to further investigate the composition of the black surface coating.

\section{Acknowledgments}

The author thanks Roger J. Dennis and Ricardo Castanheira for their opinions and help reviewing this article. To the Lisbon Military Museum staff, and director, Infantry Colonel Luís Sodré de Albuquerque, for providing access to the entire collection and particularly to this object, for its study. Maria Cristina Moura for her help and time spent in the Núcleo Museológico das Oficinas Gerais de Fardamento e Equipamento. To the Escola Superior de Tecnologia de Tomar, Conservation and Restoration professors who helped in this study, and Dr. Vítor Gaspar, responsible for the analysis. The author would also like to thank both anonymous reviewers for their thorough reviews and comments, which were a major contribution in improving this article, thus playing a role valuing this cultural object.

\section{REFERENCES}

1. Brandão, Z., Catalogo do Museu de Artilharia, $6^{\text {a }}$ ed., A Editora, Lisboa (1912).

2. G., C., 'Infanteria n. ${ }^{\circ} 27$. As suas mais urgentes necessidades', Revista de Infanteria 12(2) (1909) 40-42.

3. 'Correspondência do coronel Joaquim Zeferino Teixeira para D. Miguel Pereira Forjaz, ministro e secretário de Estado dos Negócios da Guerra sobre pessoal, administração, memória e relação dos guarda barreiras, vencimentos, relação das mochilas de víveres, abastecimento da torre de São Julião, uniformes, relação dos oficiais inferiores, soldados e artilheiros de Pé de Castelo, relação das mochilas vindas de Inglaterra e relação dos fardamentos distribuídos aos corpos', manuscrito, Arquivo Histórico Militar, Lisboa, Divisão 1, secção 14, unidade de instalação 157, documento 04, registo 0016 (1811).

4. 'Chronica Interna', Revista Militar 1(2) (1849) 115-118.

5. 'Chronica interna', Revista Militar 2(8) (1850) 393-400. 
6. 'Chronica interna', Revista Militar 2(10) (1850) 501-505.

7. Salgado, A. J., 'Uniformes-equipamento', Revista Militar 1(4) (1849) 304-307.

8. 'Noticiario militar', Revista Militar 8(3) (1856) 133-142.

9. Ordenança Sobre os Exercícios e Evoluções dos Corpos de Infanteria, vol. 1, Imprensa Nacional, Lisboa (1879).

10. Brak Lamy, A. C., Manual para a Instrucção dos Cabos e Soldados de Infanteria, Typographia da Cooperativa Militar, Lisboa (1897).

11. Cordeiro, J., 'Arsenal do exército', Revista Militar 20(5) (1868) 88-97.

12. Aragão, A. C., 'Uniformes militares', Revista Militar 38(18) (1886) 545-552.

13. M., 'Estudos militares', Revista Militar 46(12) (1894) 353-358.

14. Disposição do correame e equipamento' in Ordenança Sobre os Exercícios e Evoluções dos Corpos de Infanteria, vol. 1, Imprensa Nacional, Lisboa (1879) 13-15.

15. 'Instrucções para a limpeza e conservação do correame e equipamento' in Ordenança Sobre os Exercícios e Evoluções dos Corpos de Infanteria, vol. 1, Imprensa Nacional, Lisboa (1879) 113-114.

16. 'Baptisados 1869. Freguesia de São Miguel da Acha', manuscrito, Arquivo distrital, Castelo Branco, maço 58, n. ${ }^{\circ}$ 13/1, L. ${ }^{\circ} 10-B$ (1869).

17. 'Regimento $n .^{\circ} 2$ de caçadores da Rainha, $1^{\circ}$ batalhão. Livro de matricula do pessoal. Registo das praças de pret. Com principio em 24 de abril de 1888 . Serie $1^{\mathrm{a}}$ livro $2^{\circ}$ desde $n .^{\circ}$ 999 até 1998', manuscrito, Arquivo Histórico Militar, Lisboa, Coleção $\mathrm{G} / \mathrm{LM}$, série $\mathrm{C}$, subsérie 02 , unidade física 32, registo 0909 (1899).

18. ' 2 ' batalhão de caçadores $n .^{\circ} 2$. Livro de matricula do pessoal. Registo das praças de pret. Com principio em 4 de setembro de 1894 . Serie $1^{\mathrm{a}}$ livro $3^{\circ}$ desde $n .^{\circ} 1993$ até $2565^{\prime}$, manuscrito, Arquivo Histórico Militar, Lisboa, Coleção G/LM, série C, subsérie 02, unidade física 36, registo 0033 (1899).

19. Simões, L. H., 'Notícia histórica do regimento n. $^{\circ} 2$ de caçadores da Rainha', Revista Militar 48(8) (1896) 230-236.

20. Simões, L. H., 'Notícia histórica do regimento n. ${ }^{\circ} 2$ de caçadores da Rainha', Revista Militar 48(11) (1896) 328-335.

21. Simões, L. H., 'Notícia histórica do regimento n. $^{\circ} 2$ de caçadores da Rainha', Revista Militar 48(12) (1896) 365-376.

22. Franco, J. C. P., Legislação Militar. Principais Disposições que Constituem Materia de Execução Permanente de 1864 a 1896, vol. 2, Manoel Gomes Editor, Lisboa (1898).

23. Appelbaum, B., 'The concept of ideal state', in Conservation Treatment Methodology, ed. B. Appelbaum, CreateSpace, Lexington (2010) 173-193.

24. Appelbaum, B., 'Determining the realistic goal of treatment', in Conservation Treatment Methodology, ed. B. Appelbaum, CreateSpace, Lexington (2010) 237-269.

25. Pereira, V. P. A., 'Algumas considerações a respeito do novo systema de limpeza', Revista Militar 7(3) (1855) 109-119.

26. Chahine, C., 'Changes in hydrothermal stability of leather and parchment with deterioration: a DSC study', Thermochimica Acta 365 (2000) 101-110, https://doi.org/10.1016/ So040-6031(00)00617-1
27. Bianco, L., Avalle, M., Scattina, A., Croveri, P., Pagliero, C., Ciantore, O., 'A study on reversibility of $\mathrm{BEVA}^{\circledR} 371$ in the lining of paintings', Journal of Cultural Heritage 16 (2015) 479-485, https://dx.doi.org/10.1016/j.culher.2014.09.001

28. Ploeger, R.; McGlinchey, C.; de La Rie, E. R., 'Original and reformulated $\mathrm{BEVA}^{\circledR}$ 371: Composition and assessment as a consolidant for painted surfaces', Studies in Conservation 60(4) (2015) 217-226, https://dx.doi.org/10.1179/20470584 14Y.0000000132

29. Ploeger, R., de La Rie, E. R.; McGlinchey, C.; Palmer, M.; Maines, C. A.; Chiantore, O., 'The long-term stability of a popular heat-seal adhesive for the conservation of painted cultural objects', Polymer Degradation and Stability 107 (2014) 307-313, https://doi.org/10.1016/j.polymdegradstab.2014.01.031

30. Xu, W.; Han, E.; Wang, Z., 'Effect of tannic acid on corrosion behavior of carbon steel in $\mathrm{NaCl}$ solution', Journal of Materials Science \& Technology 35 (2019) 64-75, https://doi.org/10.1016/j. jmst.2018.09.001

31. Švadlena J.; Stoulil J., 'Evaluation of protective properties of acrylate varnishes used for conservation of historical metal artefacts', Koroze a ochrana materiálu 61(1) (2017) 25-31, https:// dx.doi.org/10.1515/kom-2017-0003

RECEIVED: 2018.12 .9

REVISED: 2019.9.6

ACCEPTED: 2020.5.28

ONLINE: 2020.7 .31

\section{(c) (1)(3) $(9)$}

This work is licensed under the Creative Commons Attribution-NonCommercial-NoDerivatives 4.0 International License. To view a copy of this license, visit http://creativecommons.org/licenses/by-nc-nd/4.o/deed.en. 